\title{
CASP3 Gene
}

National Cancer Institute

\section{Source}

National Cancer Institute. CASP3 Gene. NCI Thesaurus. Code C26574.

This gene plays a role in the execution phase of apoptosis and is involved in DNA repair. 